\title{
Hepatitis viruses infection and risk of intrahepatic cholangiocarcinoma: evidence from a meta-analysis
}

Yanming Zhou ${ }^{1+}$, Yanfang Zhao ${ }^{2 \dagger}$, Bin $\mathrm{Li}^{1}$, Jiyi Huang ${ }^{1}$, Lupeng $\mathrm{Wu}^{1}$, Donghui $\mathrm{Xu}^{1}$, Jiamei Yang ${ }^{3^{*}}$ and Jia $\mathrm{He}^{2^{*}}$

\begin{abstract}
Background: Studies investigating the association between Hepatitis B virus (HBV) and hepatitis C virus (HCV) infections and intrahepatic cholangiocarcinoma (ICC) have reported inconsistent findings. We conducted a meta-analysis of epidemiological studies to explore this relationship.

Methods: A comprehensive search was conducted to identify the eligible studies of hepatitis infections and ICC risk up to September 2011. Summary odds ratios (OR) with their 95\% confidence intervals (95\% Cl) were calculated with random-effects models using Review Manager version 5.0.

Results: Thirteen case-control studies and 3 cohort studies were included in the final analysis. The combined risk estimate of all studies showed statistically significant increased risk of ICC incidence with HBV and HCV infection $(\mathrm{OR}=3.17,95 \% \mathrm{Cl}, 1.88-5.34$, and $\mathrm{OR}=3.42,95 \% \mathrm{Cl}, 1.96-5.99$, respectively). For case-control studies alone, the combined OR of infection with HBV and HCV were $2.86(95 \% \mathrm{Cl}, 1.60-5.11)$ and $3.63(95 \% \mathrm{Cl}, 1.86-7.05)$, respectively, and for cohort studies alone, the OR of HBV and HCV infection were 5.39 (95\% Cl, 2.34-12.44) and 2.60 (95\% Cl, 1.36-4.97), respectively.
\end{abstract}

Conclusions: This study suggests that both HBV and HCV infection are associated with an increased risk of ICC.

\section{Background}

Intrahepatic cholangiocarcinoma (ICC), which originates from intrahepatic bile ducts, is the second commonest primary hepatic tumour behind hepatocellular carcinoma (HCC), accounting for $3 \%$ of all gastrointestinal cancers worldwide [1]. The etiology of ICC is poorly understood although several etiological factors, including hepatolithiasis [2], primary sclerosing cholangitis [3], liver flukes (Clonorchis sinensis and Opisthorchis viverrini) [4] and exposure to the radiopaque medium thorium dioxide (Thorotrast) [5], has been well established.

It has been shown that Hepatitis B virus (HBV) and hepatitis $\mathrm{C}$ virus (HCV) infections are the major causative agent for HCC [6]. Several recent studies have been

\footnotetext{
* Correspondence: yjm.1952@yahoo.com.cn; hejia63@yahoo.com

${ }^{\dagger}$ Equal contributors

${ }^{2}$ Department of Health Statistics, Second Military Medical University,

Shanghai, China

${ }^{3}$ Department of Special Treatment, Eastern Hepatobiliary Surgery Hospital,

Second Military Medical University, Shanghai, China

Full list of author information is available at the end of the article
}

conducted to investigate the association of ICC with viral hepatitis infections, but the conclusions remained controversial [7-15]. For example, a case-control study from Korea found neither HBV nor HCV infection was associated with the risk of ICC [7]. In contrast, a casecontrol study from Italy found that seropositivities for anti-HCV and hepatitis B surface antigen ( $\mathrm{HBsAg}$ ) were $25 \%$ and $13 \%$ in ICC cases and $5.8 \%$ and $6.7 \%$ in controls, respectively. A statistically significant increase in the odds ratios (OR) was observed for anti-HCV $(\mathrm{OR}=9.7)$, whereas no significant association was found with HBsAg $(\mathrm{OR}=2.7)$ [8]. On the other hand, the results of a casecontrol study from China showed a positive association of ICC with HBV but not with HCV [9]. Therefore, we conducted a meta-analysis to address the inconsistent results reported in previous studies, thereby improving the estimate of ICC risk in $\mathrm{HBV}$ - or $\mathrm{HCV}$ - infected patients.

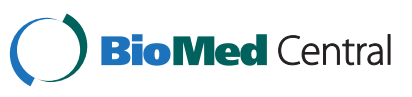

(c) 2012 Zhou et al.; licensee BioMed Central Ltd. This is an Open Access article distributed under the terms of the Creative Commons Attribution License (http://creativecommons.org/licenses/by/2.0), which permits unrestricted use, distribution, and reproduction in any medium, provided the original work is properly cited. 


\section{Methods}

\section{Study selection}

To identify the relevant literature, searches of PubMed, Embase, Ovid, Cochrane Library, and Scopus database for articles on ICC associated with HBV or HCV infection were conducted up to September 2011. The following $\mathrm{MeSH}$ (Medical Subject Heading) search headings were used: 'hepatitis B virus," "hepatitis C virus," "bile duct neoplasms", and "cholangiocarcinoma". Reference lists of all retrieved articles were manually searched for additional studies. Serum HBsAg and hepatitis C antibody were used as the positive markers of chronic hepatitis virus infection.

\section{Criteria for inclusion and exclusion}

The inclusion criteria in the meta-analysis are as follows: published full-text report in English language, studies provided sufficient data to calculate the risk estimates with its corresponding 95\% confidence interval (CI) of ICC associated with HBV or HCV infection.

Abstracts, letters, editorials and expert opinions, reviews without original data, case reports and studies lacking control groups were excluded. The following studies were also excluded: 1) those evaluating patients with $\mathrm{HCC}$ or liver metastase; 2) those with incomplete raw data; 3$)$ those with repetitive data.

\section{Data extraction}

Two reviewers (B.L. and Y.Z.) independently extracted the following parameters from published studies: the name of the first author, publication year, study design, the country in which the study was conducted, sample size, prevalence of HBV or HCV seropositivity in cases and in a control group or in cohort, and OR or hazard ratios (HR) estimates with $95 \% \mathrm{CI}$ for $\mathrm{HBV}$ or $\mathrm{HCV}$ infection and ICC.

\section{Quality assessment}

The methodological quality of the included studies assessed using a three-items scoring system measured by the study design (cohort $=1$; case-control $=0$ ), sample size $(>100=1 ; 100=0)$, and reported outcomes of interest (both $\mathrm{HBV}$ and $\mathrm{HCV}=1$; $\mathrm{HBV}$ or $\mathrm{HCV}$ only $=0$ ). Studies having a score of 2 were considered to be of high quality.

\section{Statistical methods}

The literature review refered to PRISMA statement standards. We extracted adjusted OR and HR with 95\% CI from the included studies. Summary OR was estimated using random-effects models. Heterogeneity was calculated by means of $\mathrm{Q}$ test and $\chi 2$ test. Publication bias was assessed visually using a funnel plot. All analyses were conducted using Review Manager (RevMan) software 5.0 .

\section{Results}

\section{Selection of studies}

Figure 1 shows the flow chart of publications identified by the literature search. A total of 13 case-control studies [7-19] and 3 cohort studies [20-22] were included in the meta-analysis. The main features of the studies included in the meta-analysis are shown in Tables 1 and 2. Among the 13 case-control studies, three were from United States $[10,11,15]$, three from China $[9,18,19]$, three from Korea $[7,14,16]$, one from Italy [8], one from Thailand [13], one from Taiwan [17], and one from Japan [12]. Control subjects originated from hospital-based [7-9,11-14,16-19], or general population-based population $[10,15]$.

Among the 3 cohort studies, one was from United States [20], one from Japan [21], and one from Taiwan [22]. The average observation period ranged from 2.3 to 7.6 years.

The two reviewers had 100\% agreement in their reviews of the data extraction.

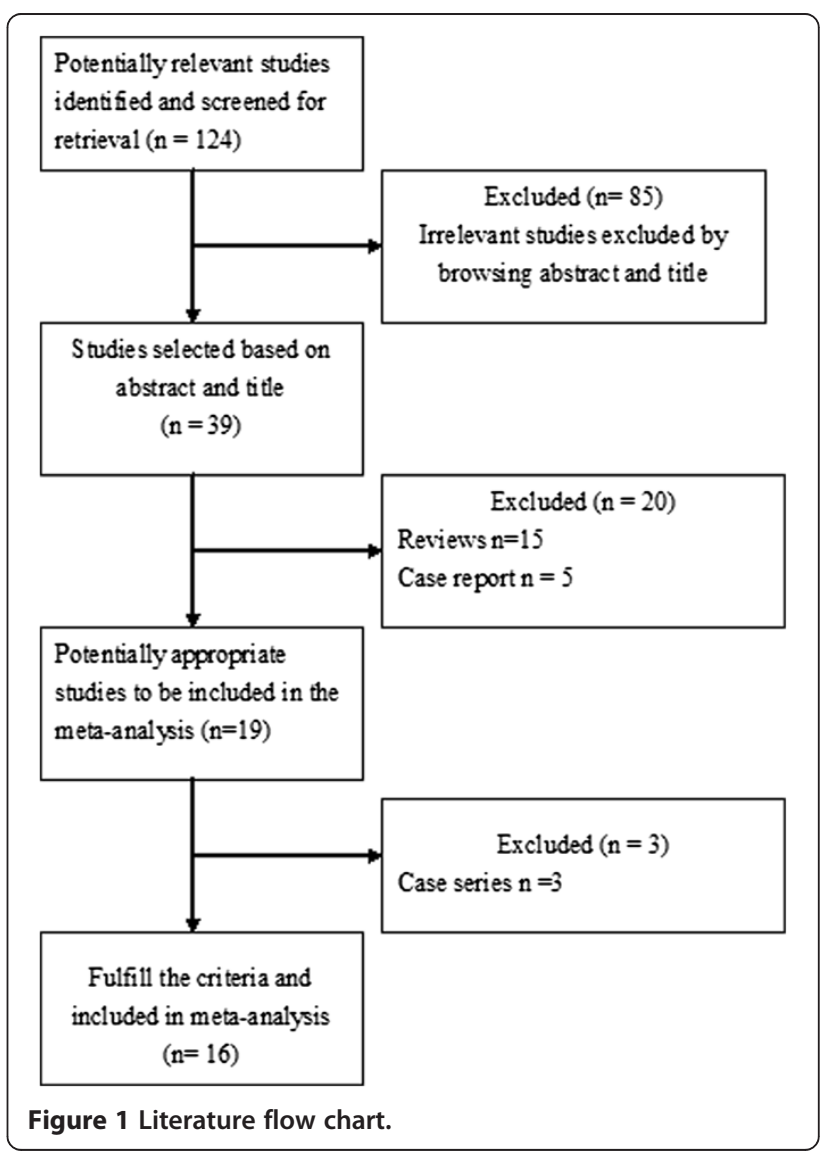


Table 1 Characteristics of case-control studies of hepatitis viruses infection and ICC risk

\begin{tabular}{lllllllll}
\hline First author & Year & Country & $\begin{array}{l}\text { Cases } \\
(\boldsymbol{n})\end{array}$ & $\begin{array}{l}\text { Control } \\
(\boldsymbol{n})\end{array}$ & Control description & $\begin{array}{l}\text { OR (95\% Cl) for } \\
\text { HBV infection }\end{array}$ & $\begin{array}{l}\text { OR (95\% Cl) for } \\
\text { HCV infection }\end{array}$ & $\begin{array}{l}\text { Study } \\
\text { quality }\end{array}$ \\
\hline Parkin & 1991 & Thailand & 100 & 100 & Hospital-based control & $1.0(0.4-2.1)$ & - & 1 \\
\hline Shin & 1996 & Korea & 41 & 406 & Hospital-based control & $1.3(0.3-5.3)$ & $3.9(0.9-17.1)$ \\
\hline Donato & 2001 & Italy & 26 & 824 & Hospital-based control & $2.7(0.4-18.5)$ & $9.7(1.6-58.9)$ & 2 \\
\hline Yamamoto & 2004 & Japan & 50 & 205 & Hospital-based control & $1.8(0.3-10.1)$ & $16.8(5.7-50.0)$ & 2 \\
\hline Shaib & 2005 & US & 625 & 90834 & Population-based control & $0.8(0.1-5.9)$ & $6.1(4.3-8.6)$ & 2 \\
\hline Choi & 2006 & Korea & 185 & 185 & Hospital-based control & $0.8(0.198-3.023)$ & $1.0(0.04-25.264)$ & 2 \\
\hline Shaib & 2007 & US & 83 & 236 & Hospital-based control & $2.9(0.1-236.8)$ & $7.9(1.3-84.5)$ & 2 \\
\hline Welzel & 2007 & US & 535 & 102782 & Population based control & - & $4.4(1.4-14.0)$ & 1 \\
\hline Lee & 2008 & Korea & 622 & 2488 & Hospital-based control & $2.3(1.6-3.3)$ & $1.0(0.5-1.9)$ & 2 \\
\hline Zhou & 2008 & China & 312 & 438 & Hospital-based control & $8.876(5.98-13.19)$ & $0.933(0.281-3.1)$ & 2 \\
\hline Lee & 2009 & Taiwan & 160 & 160 & Hospital-based control & $4.985(2.78-8.95)$ & $2.71(1.16-6.32)$ & 2 \\
\hline Tao & 2010 & China & 61 & 380 & Hospital-based control & $18.1(7.5-44.0)$ & - & 1 \\
\hline Peng & 2011 & China & 98 & 196 & Hospital-based control & $2.75(1.27-5.95)$ & -
\end{tabular}

$\mathrm{ICC}$, intrahepatic cholangiocarcinoma; $\mathrm{HBV}$, hepatitis B virus; $\mathrm{HCV}$, hepatitis $\mathrm{C}$ virus; US, United States.

\section{Meta-analysis}

Meta-analysis of all these 16 studies in a random-effects model found statistically significant increased risk of ICC incidence with HBV and HCV infection $(\mathrm{OR}=3.17$, 95\% CI, 1.88-5.34, $P<0.001$ and OR $=3.42$, 95\% CI,1.965.99, $P<0.001$, respectively). When case-control studies were analyzed alone, the combined OR for the association of $\mathrm{HBV}$ and $\mathrm{HCV}$ infection with the risk for ICC were 2.86 (95\% CI, 1.60-5.11) and 3.63 (95\% CI, 1.86-7.05), respectively. When cohort studies were analyzed alone, the combined OR of HBV and HCV infection were 5.39 (95\% CI, 2.34-12.44) and 2.60 (95\% CI, 1.36-4.97), respectively. All these results were significant heterogeneous $(P<0.001)$ (Figures 2 and 3$)$.

\section{Sensitivity analysis of high quality studies}

Analysis of these studies [7-12,14,16,17,20-22] revealed both HBV $(\mathrm{OR}=3.10,95 \% \mathrm{CI}, 1.77-5.42, P<0.001)$ and $\mathrm{HCV}$ infection $(\mathrm{OR}=3.35,95 \% \mathrm{CI}, 1.82-6.15, P<0.001)$ were associated with significant increased risk of ICC development.

\section{Publication bias}

A "funnel plot" of the studies in the meta-analysis reporting HBV infection and ICC is shown in Figure 4. Five of the studies lay outside the $95 \%$ confidence interval boundaries, and significant heterogeneity was observed.

\section{Discussion}

Meta-analysis was employed by a recently published study to estimate the correlation between hepatitis virus infection and the risk of ICC and extrahepatic cholangiocarcinoma (ECC) [23]. Because different anatomic location of CC has distinct epidemiologic features indicating different sets of risk factors [11], here we used meta-analysis to examine the relationship between $\mathrm{HBV} / \mathrm{HCV}$ infection and the risks of ICC, and restricted our analysis to patients only with ICC.

In this meta-analysis, we found positive relationship between $\mathrm{HBV} / \mathrm{HCV}$ infection and the development of ICC. This conclusion is further supported by the evidences from a series of experimental studies. In a study from the United States, HBV and/or HCV DNA was present in $3(27 \%)$ out of 11 ICC tissue samples obtained

Table 2 Characteristics of cohort studies of hepatitis viruses infection and ICC risk

\begin{tabular}{|c|c|c|c|c|c|c|c|c|}
\hline First author & Year & Country & Source & Sample size & Mean follow-up (years) & ICC & Hazard ratio $95 \% \mathrm{Cl}$ & Study ,quality \\
\hline \multirow[t]{3}{*}{ Tanaka } & 2009 & Japan & Voluntary blood donors & $2519(\mathrm{HBsAg}+)$ & 7.6 & 2 & $8.56(1.33-55.2)$ & 3 \\
\hline & & & & 1927 (anti-HCV+) & & 1 & $2.63(.25-27.73)$ & \\
\hline & & & & 150368 (all negative) & & 8 & & \\
\hline \multirow[t]{2}{*}{ El-Serag } & 2009 & US & Veterans population & 146394 (anti-HCV+) & 2.3 & 14 & $2.6(1.3-5.0)$ & 2 \\
\hline & & & & 572293 (anti-HCV-) & & 23 & & \\
\hline \multirow[t]{2}{*}{ Fwu } & 2011 & Taiwan & Pregnant women & $289992(\mathrm{HBsAg}+)$ & 6.91 & 9 & $4.80(1.88-12.2)$ & 2 \\
\hline & & & & 1492409 (HBsAg -) & & 9 & & \\
\hline
\end{tabular}

ICC, intrahepatic cholangiocarcinoma; HBsAg, hepatitis B surface antigen; HCV, hepatitis C virus; US, United States. 


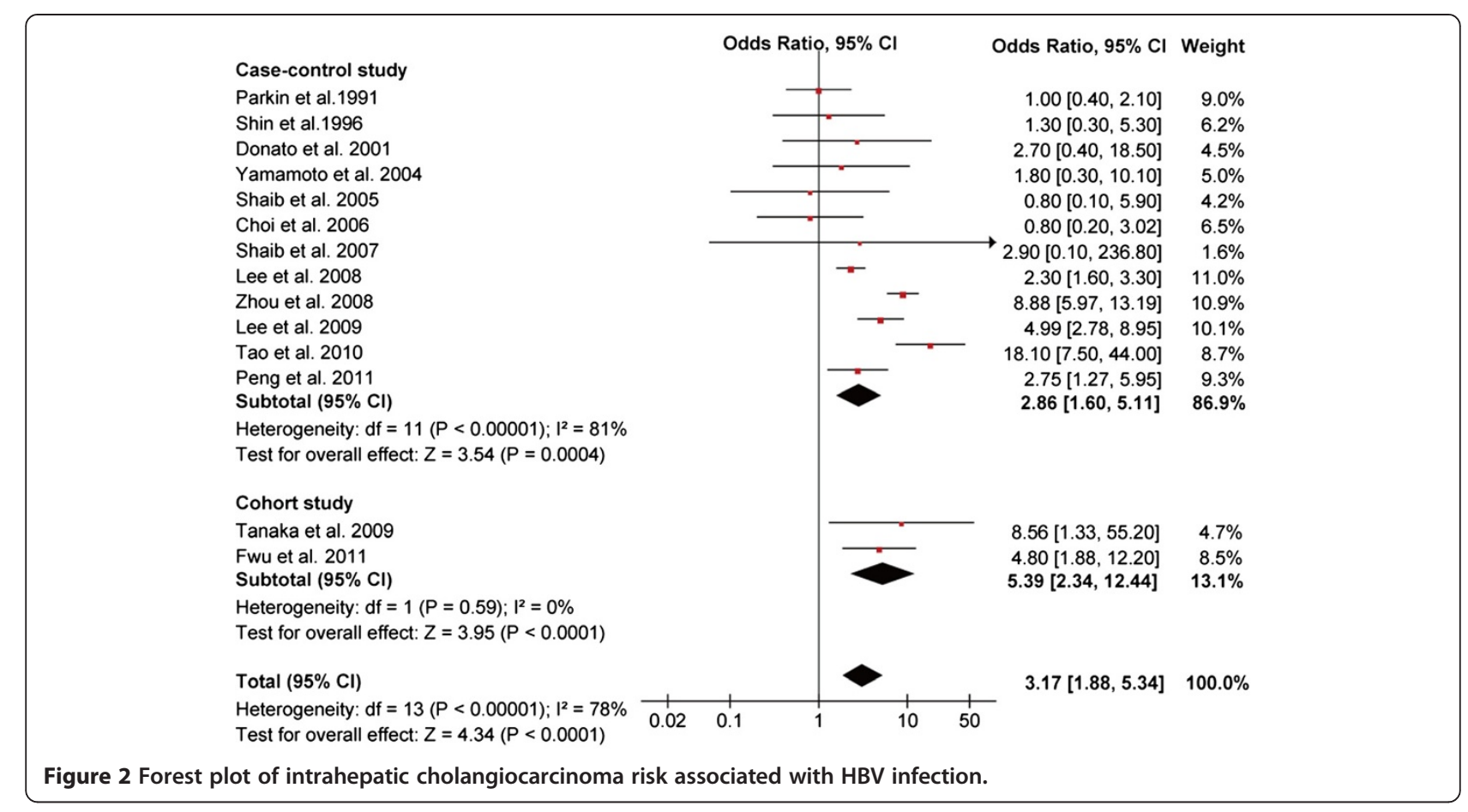

at the time of surgical resection [24]. Another study from China also showed that HBV DNA was detected in $34.8 \%(8 / 23)$ of ICC cases [25]. Recently, Torbenson et al. [26] found that dysplasia of the intrahepatic bile ducts, the histologic precursor lesion of ICC, was present in $\mathrm{HCV}$ related cirrhotic livers.

The mechanism of the development of ICC in patients with $\mathrm{HBV}$ or $\mathrm{HCV}$ infection is still uncertain. HBV and

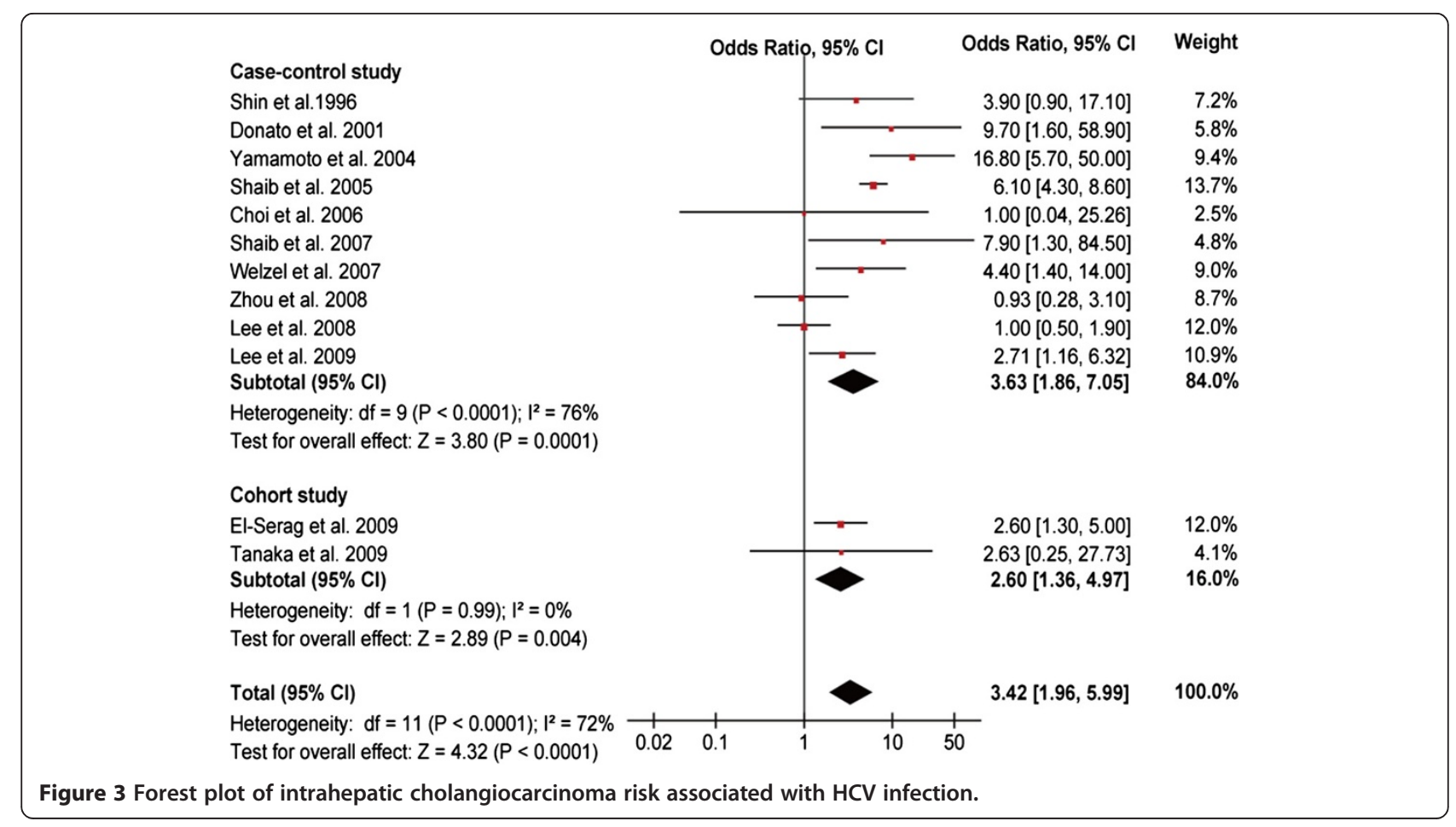




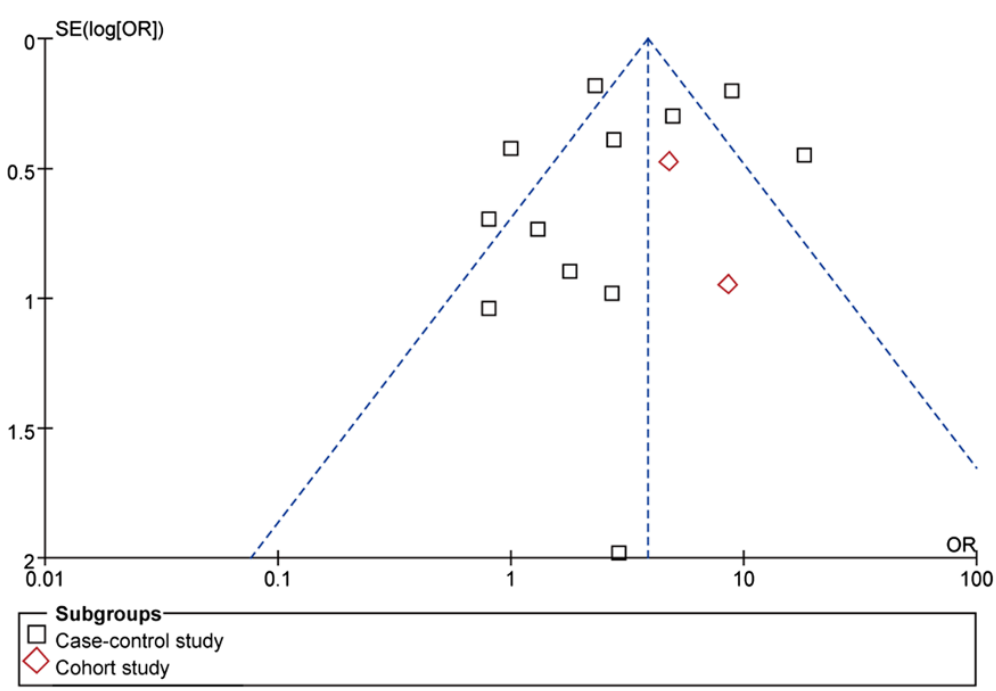

Figure 4 Funnel plot of studies evaluating the association between HBV infection and intrahepatic cholangiocarcinoma risk.

$\mathrm{HCV}$ infection can cause chronic inflammation of the liver. Indeed, chronic inflammation and cancer are closely associated. In this context, long-term expression of several viral oncoproteins, mostly the HCV core protein and HBx protein, might participate in the tumourigenic process. Battaglia et al. [27] found that HCC derived-HCV core variants alleviate TGF-beta cytostatic responses and increase TGF-beta-mediated epithelial to mesenchymal transition (EMT) in mouse or human primary hepatocytes. Interestingly, Li et al. [28] reported that $\mathrm{HCV}$ core protein expression can induce EMT in cholangiocarcinoma cell line. On the other hand, HBx acting as a transactivator on various cellular genes that are involved in the control of the cell cycle, proliferation or apoptosis has been shown to be present in some HBV-infected ICC specimens [29]. There are reports providing evidence that $\mathrm{HBx}$ gene transfection can upregulate the transcriptional expression of human telomerase reverse transcriptase mRNA both in $\mathrm{HCC}$ and cholangiocarcinoma cell lines [30]. Clinically, Peng et al. [19] reported that ICC patients with HBV infection were more common in male and younger patients as compared to ICC patients with seronegative HBsAg, similar to HCC patients. Furthermore, the profile of age distribution of ICC patients with HBV infection was roughly close to that of HCC patients. Similarly, Lee et al. [17] also found that both viral hepatitis-associated ICC and HCC had similar age profiles and difference in age distributions between patients with chronic hepatitis $\mathrm{B}$ and patients with chronic hepatitis $\mathrm{C}$. In addition, the surgical outcomes of ICC patients with hepatitis, preoperatively diagnosed as $\mathrm{HCC}$, is favorable, similar to that of typical HCC patients [31]. Taking these clinical and experimental findings into account, it seems to be reasonable that hepatitis virus-associated ICC and HCC share common disease processes for carcinogenesis.

Some researchers suggest that hepatocytes and cholangiocytes might originate from hepatic progenitor cells (HPCs) [32]. Therefore it is possible that both ICC and $\mathrm{HCC}$ in patients infected with $\mathrm{HBV}$ and $\mathrm{HCV}$ may be derived from HPCs. In fact, cumulative studies have provided strong evidence to this hypothesis. Cumulative evidence suggests that $\mathrm{HBV}$ - and $\mathrm{HCV}$-associated HCC and ICC are derived from HPCs. (i) It has been demonstrated that HPCs can be infected with HBV and HCV, and that proliferation of large numbers of HPCs was seen in HBV- and HCV-associated cirrhosis which is a risk factor for liver cancer [33,34]. (ii) Based on gross morphological features, ICC are classifiable into three representative types of growth patterns: the massforming (MF) type, the periductal infiltrating (PI) type, and the intraductal growth (IG) type [35]. It is likely that PI and IG type tumors arise from malignant transformation of epithelial cells lining the larger bile ducts, whereas the MF type arises from smaller bile ducts or liver progenitor cells within portal areas [36]. Yamamoto et al. [37] speculated that HCV-infected proliferating cholangioles in patients with chronic hepatitis $\mathrm{C}$ might be associated with the development of MF type ICC. Yu et al. [36] found that viral hepatitis-associated ICC was more likely to be of the MF type rather than the PI and IG type. (iii) Alpha-fetoprotein (AFP) is a marker of HPCs compartments [38]. Viral hepatitis-associated ICC patients were found had elevated serum alpha-fetoprotein levels as compared with seronegative ICC patients $[19,36]$. One possible mechanism for the development of ICC is that the neoplastic transformation of HPCs is involved in the genesis of ICC and that the HPCs retain their ability 
to produce AFP through the process of malignant transformation [38]. Indeed, Ishii et al. [39] demonstrated that AFP-producing cells in cholangiocarcinomas possessed cancer stem cell-like properties. More importantly, one most recent study from China found that HBx induces intrinsic cellular transformation, promoting the expansion and tumorigenicity of HPCs in 3,5-diethoxycarbonyl- 1, 4-dihydrocollidine treated mice [40].

ICC is characterized by wide variability in incidence and risk factors. $\mathrm{HCV}$ seems to be associated with ICC in regions with relatively low prevalence of HBV infection such as United States, Italy and Japan. In contrast, several studies from China $[9,18,19]$, a highly endemic area for HBV infection, found that not HCV but HBV infection was significantly associated with ICC. On the other hand, a recent study from Taiwan, where both HBV and ICC are endemic, found that both HBV and $\mathrm{HCV}$ are significantly associated with ICC [17]. These studies indicate that the different endemic hepatitis virus types in different regions may be a determinant to the variability of risk factors for ICC.

Our study also has some weaknesses which should be considered when interpreting results. First, seropositivity for $\mathrm{HBsAg}$ and anti-HCV was used as the sole indicator of $\mathrm{HBV}$ and $\mathrm{HCV}$ infection. It seems that occult HBV and $\mathrm{HCV}$ infection may also play a role in the development of HCC [41]. Therefore, the definition in the present report might result in underestimation of the effect of hepatitis viruses infection. Second, there were significant heterogeneities between different studies, which would lower the reliability of the summary odds ratio. The presence of heterogeneity is most likely to have been introduced by diversity in study design, population demographics, location of studies conducted and adjustments for confounders. Finally, the possibility of publication bias is of concern. The fact that studies with positive results are more likely to be published than negative and non-English studies were excluded in the current meta-analysis might be sources of potential publication bias.

\section{Conclusions}

In conclusion, in this meta-analysis of 13 case-control studies and 3 cohorts, we found that HBV and HCV infection are associated with an increased risk of ICC.

\section{Competing interests}

The authors declare that they have no competing interests.

\footnotetext{
Author details

${ }^{1}$ Department of Hepato-Biliary-Pancreato-Vascular Surgery, First affiliated Hospital of Xiamen University, Xiamen, China. ${ }^{2}$ Department of Health Statistics, Second Military Medical University, Shanghai, China. ${ }^{3}$ Department of Special Treatment, Eastern Hepatobiliary Surgery Hospital, Second Military Medical University, Shanghai, China.
}

\section{Authors' contributions}

YZ participated in the design and coordination of the study, carried out the critical appraisal of studies and wrote the manuscript. BL, LW, JH, and DX developed the literature search, carried out the extraction of data, assisted in the critical appraisal of included studies and assisted in writing up. $Y Z$ and $\mathrm{JH}$ carried out the statistical analysis of studies. YZ and JY interpreted data, corrected and approve the manuscript. All authors read and approved the final manuscript.

Received: 8 February 2012 Accepted: 16 July 2012

Published: 16 July 2012

\section{References}

1. Khan SA, Thomas HC, Davidson BR, Taylor-Robinson SD: Cholangiocarcinoma. Lancet 2005, 366:1303-1314.

2. Liu ZY, Zhou YM, Shi LH, Yin ZF: Risk factors of intrahepatic cholangiocarcinoma in patients with hepatolithiasis: a case-control study. Hepatobiliary Pancreat Dis Int 2011, 10:626-631.

3. Broome U, Lofberg R, Veress B, Eriksson LS: Primary sclerosing cholangitis and ulcerative colitis: evidence for increased neoplastic potential. Hepatology 1995, 22:1404-1208.

4. Watanapa P, Watanapa WB: Liver fluke-associated cholangiocarcinoma. Br J Surg 2002, 89:962-970.

5. Zhu AX, Lauwers GY, Tanabe KK: Cholangiocarcinoma in association with Thorotrast exposure. J Hepatobiliary Pancreat Surg 2004, 11:430-433.

6. Zemel R, Issachar A, Tur-Kaspa R: The role of oncogenic viruses in the pathogenesis of hepatocellular carcinoma. Clin Liver Dis 2011, 15:261-279. vii-x.

7. Shin HR, Lee CU, Park HJ, Seol SY, Chung JM, Choi HC, Ahn YO, Shigemastu T: Hepatitis B and C virus, Clonorchis sinensis for the risk of liver cancer: a case-control study in Pusan, Korea. Int J Epidemio/ 1996, 25:933-940.

8. Donato F, Gelatti U, Tagger A, Favret M, Ribero ML, Callea F, Martelli C, Savio A, Trevisi P, Nardi G: Intrahepatic cholangiocarcinoma and hepatitis $C$ and $B$ virus infection, alcohol intake, and hepatolithiasis: a case-control study in Italy. Cancer Causes Control 2001, 12:959-964.

9. Zhou YM, Yin ZF, Yang JM, Li B, Shao WY, Xu F, Wang YL, Li DQ: Risk factors for intrahepatic cholangiocarcinoma: a case-control study in China. World J Gastroenterol 2008, 14:632-635.

10. Shaib YH, El-Serag HB, Davila JA, Morgan R, McGlynn KA: Risk factors of intrahepatic cholangiocarcinoma in the United States: a case-control study. Gastroenterology 2005, 128:620-626.

11. Shaib YH, El-Serag HB, Nooka AK, Thomas M, Brown TD, Patt YZ, Hassan MM: Risk factors for intrahepatic and extrahepatic cholangiocarcinoma: a hospital-based case-control study. Am J Gastroenterol 2007, 102:1016-1021.

12. Yamamoto S, Kubo S, Hai S, Uenishi T, Yamamoto T, Shuto T, Takemura S, Tanaka $\mathrm{H}$, Yamazaki O, Hirohashi K, Tanaka T: Hepatitis C virus infection as a likely etiology of intrahepatic cholangiocarcinoma. Cancer Sci 2004, 95:592-595.

13. Parkin DM, Srivatanakul P, Khlat M, Chenvidhya D, Chotiwan P, Insiripong S, L'Abbé KA, Wild CP: Liver cancer in Thailand. I. A case-control study of cholangiocarcinoma. Int J Cancer 1991, 48:323-328.

14. Choi D, Lim JH, Lee KT, Lee JK, Choi SH, Heo JS, Jang KT, Lee NY, Kim S, Hong ST: Cholangiocarcinoma and Clonorchis sinensis infection: a case-control study in Korea. J Hepatol 2006, 44:1066-1073.

15. Welzel TM, Graubard BI, El-Serag HB, Shaib YH, Hsing AW, Davila JA, McGlynn KA: Risk factors for intrahepatic and extrahepatic cholangiocarcinoma in the United States: a population-based case-control study. Clin Gastroenterol Hepatol 2007, 5:1221-1228.

16. Lee TY, Lee SS, Jung SW, Jeon SH, Yun SC, Oh HC, Kwon S, Lee SK, Seo DW, Kim MH, Suh DJ: Hepatitis B virus infection and intrahepatic cholangiocarcinoma in Korea: a case-control study. Am J Gastroenterol 2008, 103:1716-1720.

17. Lee CH, Chang CJ, Lin YJ, Yeh CN, Chen MF, Hsieh SY: Viral hepatitis-associated intrahepatic cholangiocarcinoma shares common disease processes with hepatocellular carcinoma. Br J Cancer 2009, 100:1765-1770.

18. Tao LY, He XD, Qu Q, Cai L, Liu W, Zhou L, Zhang SM: Risk factors for intrahepatic and extrahepatic cholangiocarcinoma: a case-control study in China. Liver Int 2010, 30:215-221.

19. Peng NF, Li LQ, Qin X, Guo Y, Peng T, Xiao KY, Chen XG, Yang YF, Su ZX, Chen B, Su M, Qi LN: Evaluation of risk factors and clinicopathologic 
features for intrahepatic cholangiocarcinoma in Southern China: a possible role of hepatitis B virus. Ann Surg Oncol 2011, 18:1258-1266.

20. El-Serag HB, Engels EA, Landgren O, Chiao E, Henderson L, Amaratunge HC, Giordano TP: Risk of hepatobiliary and pancreatic cancers after hepatitis C virus infection: A population-based study of U.S. veterans. Hepatology 2009, 49:116-123.

21. Tanaka M, Tanaka H, Tsukuma H, loka A, Oshima A, Nakahara T: Risk factors for intrahepatic cholangiocarcinoma: a possible role of hepatitis $B$ virus. J Viral Hepat 2010, 17:742-748.

22. Fwu CW, Chien YC, You SL, Nelson KE, Kirk GD, Kuo HS, Feinleib M, Chen CJ: Hepatitis $B$ virus infection and risk of intrahepatic cholangiocarcinoma and non-Hodgkin lymphoma: a cohort study of parous women in Taiwan. Hepatology 2011, 53:1217-1225.

23. Shin HR, Oh JK, Masuyer E, Curado MP, Bouvard V, Fang YY, Wiangnon S, Sripa B, Hong ST: Epidemiology of cholangiocarcinoma: an update focusing on risk factors. Cancer Sci 2010, 101:579-585.

24. Perumal V, Wang J, Thuluvath $P$, Choti M, Torbenson M: Hepatitis C and hepatitis $B$ nucleic acids are present in intrahepatic cholangiocarcinomas from the United States. Hum Pathol 2006, 37:1211-1216.

25. Wu Y, Wang T, Ye S, Zhao R, Bai X, Wu Y, Abe K, Jin X: Detection of hepatitis $B$ virus DNA in paraffin-embedded intrahepatic and extrahepatic cholangiocarcinoma tissue in the northern Chinese population. Hum Pathol 2012, 43:56-61.

26. Torbenson M, Yeh MM, Abraham SC: Bile duct dysplasia in the setting of chronic hepatitis C and alcohol cirrhosis. Am J Surg Pathol 2007, 31:1410-1413.

27. Battaglia S, Benzoubir N, Nobilet $S$, Charneau P, Samuel D, Zignego AL, Atfi A, Bréchot C, Bourgeade MF: Liver cancer-derived hepatitis C virus core proteins shift TGF-beta responses from tumor suppression to epithelial-mesenchymal transition. PLOS One 2009, 4:e4355.

28. Li T, Li D, Cheng L, Wu H, Gao Z, Liu Z, Jiang W, Gao YH, Tian F, Zhao L, Wang S: Epithelial-mesenchymal transition induced by hepatitis $C$ virus core protein in cholangiocarcinoma. Ann Surg Oncol 2010, 17:1937-1944.

29. Wang WL, Gu GY, Hu M: Expression and significance of HBV genes and their antigens in human primary intrahepatic cholangiocarcinoma. World J Gastroenterol 1998, 4:392-396.

30. Qu ZL, Zou SQ, Cui NQ, Wu XZ, Qin MF, Kong D, Zhou ZL: Upregulation of human telomerase reverse transcriptase mRNA expression by in vitro transfection of hepatitis $B$ virus $X$ gene into human hepatocarcinoma and cholangiocarcinoma cells. World J Gastroenterol 2005, 11:5627-5632.

31. Yamamoto M, Ariizumi S, Otsubo T, Katsuragawa H, Katagiri S, Nakano M, Takasaki K: Intrahepatic cholangiocarcinoma diagnosed preoperatively as hepatocellular carcinoma. J Surg Oncol 2004, 87:80-83.

32. Alison MR: Liver stem cells: implications for hepatocarcinogenesis. Stem Cell Rev 2005, 1:253-260.

33. Lowes KN, Brennan BA, Yeoh GC, Olynyk JK: Oval cell numbers in human chronic liver diseases are directly related to disease severity. Am J Pathol 1999, 154:537-541.

34. Xiao JC, Jin XL, Ruck P, Adam A, Kaiserling E: Hepatic progenitor cells in human liver cirrhosis: immunohistochemical, electron microscopic and immunofluorencence confocal microscopic findings. World J Gastroenterol 2004, 10:1208-1211.

35. Yamasaki S: Intrahepatic cholangiocarcinoma: macroscopic type and stage classification. J Hepatobiliary Pancreat Surg 2003, 10:288-291.

36. Yu TH, Yuan RH, Chen YL, Yang WC, Hsu HC, Jeng YM: Viral hepatitis is associated with intrahepatic cholangiocarcinoma with cholangiolar differentiation and N-cadherin expression. Mod Pathol 2011, 24:810-819.

37. Yamamoto M, Takasaki K, Nakano M, Saito A: Minute nodular intrahepatic cholangiocarcinoma. Cancer 1998, 82:2145-2149.

38. Ishikawa K, Sasaki A, Haraguchi N, Yoshikawa Y, Mori M: A case of an alpha-fetoprotein-producing intrahepatic cholangiocarcinoma suggests probable cancer stem cell origin. Oncologist 2007, 12:320-324.

39. Ishii T, Yasuchika K, Suemori H, Nakatsuji N, Ikai I, Uemoto S: Alpha-fetoprotein producing cells act as cancer progenitor cells in human cholangiocarcinoma. Cancer Let 2010, 294:25-34.

40. Wang C, Yang W, Yan HX, Luo T, Zhang J, Tang L, Wu FQ, Zhang HL, Yu LX, Zheng LY, Li YQ, Dong W, He YQ, Liu Q, Zou SS, Lin Y, Hu L, Li Z, Wu MC, Wang HY: HBx induces tumorigenicity of hepatic progenitor cells in 3,5-diethoxycarbonyl-1,4-dihydrocollidine (DDC) treated HBx transgenic mice. Hepatology 2012, 55:108-120.
41. Shi Y, Wu YH, Wu W, Zhang WJ, Yang J, Chen Z: Association between occult hepatitis B infection and the risk of hepatocellular carcinoma: a meta-analysis. Liver Int 2012, 32:231-240.

doi:10.1186/1471-2407-12-289

Cite this article as: Zhou et al:: Hepatitis viruses infection and risk of intrahepatic cholangiocarcinoma: evidence from a meta-analysis. BMC Cancer 2012 12:289.

\section{Submit your next manuscript to BioMed Central and take full advantage of:}

- Convenient online submission

- Thorough peer review

- No space constraints or color figure charges

- Immediate publication on acceptance

- Inclusion in PubMed, CAS, Scopus and Google Scholar

- Research which is freely available for redistribution

Submit your manuscript at www.biomedcentral.com/submit
C Biomed Central 